\title{
ROMANCE IN THE WORKPLACE: ANALYSIS OF JUSTICE PERCEPTION TOWARD POLICIES CONCERNING ROMANCE IN THE WORKPLACE
}

\author{
Muhammad Irfan Syaebani \\ Riani Rachmawati \\ Departemen Manajemen, Fakultas Ekonomi dan Bisnis, Universitas Indonesia \\ e-mail: muhammad.irfan11@vi.ac.id; riani.rachmawati@ui.ac.id
}

\begin{abstract}
Romance in the workplace is a common phenomenon and inevitable from organization dynamics. Romance in the workplace has double effects to the organization: positive and negative. Therefore, organization must be careful in formulating policies concerning this phenomenon. Literature said that in formulation policies concerning romance in the workplace it must be started from organizational justice theory. This research tries to find out what policies which perceived as the most fair. Quasi experiment method with scenario instrument is chosen. This method allows experiment subjects to give response to different combinations/varieties of romance in the workplace based on 4 criterias (type of romance origin of couple - impact of romance - romance policies). Subject of experiment is master students of management study program in Universitas Indonesia who has working experiences as condition for participating and 30 students agreed to partake in experiment. Result shows that giving counseling is perceived as the most fair policy for all combinations/varieties of romance in the workplace. It shows that organization's response to romance in the workplace should not coercive policies.
\end{abstract}

Keywords: Romance in the workplace, organizational justice, organization's policy 


\section{Muhammad Irfan Syaebani \\ Riani Rachmawati}

\section{Introduction}

Based on research in US, almost one third of couples meet their partner in workplace (Bordwin, 1994). Moreover, a survey conducted by Society for Human Resource Management in 2001 revealed that $37 \%$ of respondents engaged in workplace romance. The number rose to $40 \%$ in 2005 (Parks, 2006). The same survey in 2009 also found that $40 \%$ of the respondents engaged in workplace romance (Parks, 2010).

The facts showed that romance could happen anywhere, even in the workplace. Fisher (1994, in Karl and Sutton, 2000) said workplace is the best place to find love partner and have some romantic relation. Most people who work in the same organization have similar background and aspiration. It leads to the feeling of closeness and this feeling was seed for love to grow.

Increasing number of women entering professional work was also considered as a factor that raised workplace romance (Pierce and Aguinis, 2001). Workplace romance is different from sexual harassment. Workplace romance involves mutual attractiveness while sexual harassment involves undesirable feelings and behaviors (Pierce and Aguinis, 2001). Workplace romance becomes common phenomenon and impacting organizational productivity (Anderson and Hunsaker, 1985; Dillard, 1987; Dillard and Broetzmann, 1989 in Pierce, Bryne, and Aguinis, 1996), work motivation (Mainiero, 1989, in Pierce, Bryne, and Aguinis, 1996), and organizational decision making process (Driscoll and Bova, 1980 in Pierce, Bryne, and Aguinis, 1996).

Even though workplace romance is something common, many organizations have no policies responding this issue (Parks, 2006). This issue is sensitive and the effect is double; positive and negative. A survey of Society for Human Resource Management in 2001 found $75 \%$ of organization participated in survey did not have any policies concerning workplace romance. In 2005 the same survey revealed the number almost similar, $72 \%$ of organizations participated in survey have not any policies about this issue.

Research conducted by Shellenbarger $(2008$, in Kumar, 2012) found the same pattern as it was in US. Around $88 \%$ organization participation in the research did not have any policies responding workplace romance. In fact, many managers neglecting this issue (Lickey, Berry, and Whelan-Berry, 2009). They thought if they involved in this issue, it is like waking up a sleeping dragon-beast. Thus it makes managers too late anticipating the negative effect of this issue and workplace romance already distracted the organization (Lickey, Berry, and Whelan-Berry, 2009).

Workplace romance has double effect; positive and negative. If this issue is not well managed, the negative effect will be bigger than the positive effect. Ariani, Ebrahimi, and 


\section{Jurnal Manajemen Teori dan Terapan \\ Tahun 10. No. 2, Agustus 2017}

Saaeedi (2011) said if workplace romance is a long-term relation and based on sincere love and managed well by the organization it could improve the quality of interpersonal relationship in the long run. Another research stated if workplace romance runs well, employees' productivity could rise up (Quinn, 1977; Pierce, 1998 in Ariani, Ebrahimi and Saeedi, 2011 ). Workplace romance also has positive correlation with job satisfaction (Pierce and Aguinis, 2003). Positive correlation was found between workplace romance and job involvement and between workplace romance and organizational commitment (Dillard, 1997; in Pierce and Aguinis, 2003; Ariani, Ebrahimi, and Saeedi, 2011).

The negative consequences of workplace romance are prevalent. It is very possible that this relation ends up in sexual harassment as Clarke (2006) and Schultz (2003 in Ariani, Ebrahimi, and Saeedi, 2011) found. Also, workplace romance could be an unethical relation if this relation was aimed to certain agendas, especially for hierarchical love relation between subordinate and super ordinate.

If organization mismanaged workplace romance, employees may feel injustice since it is something private. If workplace romance ended in an undesirable condition it will affect to the couple's productivity (Powell, 2001 in Ariani, Ebrahimi, and Saeedi, 2011).

Many organizations hesitate in formulating policies responding workplace romance (Cole, 2009). On one side, it is something private but on another side this issue may affect organization. Organization must ensure that the policies protecting both employees' privacy and organization well-being.

Karl and Sutton (2000) suggested in formulating policies concerning workplace romance, organization should start from organizational justice perspective. The policies should ensure justice perception so that the employees may not feel mistreated by organization but at the same time organization is protected from negative effects of workplace romance. Karl and Sutton (2000) found that lenient policy is perceived as the most just for responding workplace romance and strict policies are not suggested to implement except if workplace romance gives negative impact to organization. The finding of Karl and Sutton was re-exercised to ensure whether the Karl and Sutton's conclusion could be generalized in Indonesian context. It is important to make organizations in Indonesia have solid foundation and reliable argument in formulating correct policies about workplace romance.

Therefore, the research question is; what kind of policies perceived as the most fair in responding different kinds of workplace romance in Indonesian work setting. 


\section{Muhammad Irfan Syaebani \\ Riani Rachmawati}

\section{Literature Review}

\section{Workplace Romance}

Workplace romance is byproduct of the women entering professional workspace (Boyd, 2010). Afterwards, interaction between men and women required by their job characteristic makes workplace romance flourishing than ever before (Fisher, 1994 in Karl and Sutton, 2000). Besides increasing number of women entering professional workspace, increasing number of working hours also contributed to the occurrence of workplace romance (Appelbaum et al, 2007). Based on research in Canada, in last two decades the working hours rose in average from 8.2 hours per day in 1986 to 8.6 hours per day in 2005 (Appelbaum et al, 2007).

In previous era, workplace romance considered as something inappropriate. Therefore, workplace romance often responded harshly by organization even though the relationship does not break any legal rules and it is also not an affair or extra-marital relationship (Mainiero, 1989 in Cole, 2009). In fact, romance could happen anywhere, including in workplace. If organization responds too harsh, employees may feel that they are being treated unfairly since many people think romance as something private (Fisher, 1994 in Cole, 2009). Organization must responds carefully because it could be mismanagement for organization if the policies are not well formulated (Cole, 2009).

Quinn (1997); Foley and Powell (1999), and Pierce (1998) cited by Ariani, Ebrahimi, dan Saeedi (2011) define workplace romance as; "A mutually desired relationship that includes physical attraction between two members of the same organization (Ariani, Ebrahimi, Saeedi; 2011, p. 100)." The definition clearly said that workplace romance involving 2 persons working in same organization. The nature of workplace romance is mutualism which means both parties are willing to engage in the relationship and excluding any undesirable behaviors. This is differentiating workplace romance from sexual harassment (Fitzgerald, Gelfand, Drasgow; 1995 in Pierce and Aguinis; 2001).

Moreover, Ariani, Ebrahimi, and Saeedi (2011) said that workplace romance has several characteristics, which are; willingness from both parties to stick together, involving emotional and physical attraction from both parties, willingness to share, mutual caring and mutual respect, and may involving sexual behavior such as kissing, hugging, or even intercourse. According to Karl and Sutton (2000), workplace romance could be between super ordinate and subordinate (hierarchical) or between co-workers (lateral) and the parties may come from the same division or different division.

Workplace romance also can be differentiated by motive. Pierce and Aguinis (2001) classified workplace romance motives into 3 categories; sincere motive, fling motive, and 


\section{Jurnal Manajemen Teori dan Terapan \\ Tahun 10. No. 2, Agustus 2017}

utilitarian motive. Couple with sincere motive based their relation on sincere love. They want to build long-term relation and commitment. In fling motive, couple engages in relationship solely for pleasure seeking. They do not want to build long-term relation and commitment. In utilitarian motive parties engaged in relationship use this relation to secure their job position or to seek for power. Long-term relation and commitment are excluding in this motive. Workplace romance only means to gain certain status in organization.

As stated before, workplace romance has double effects to organization; positive and negative. The impact also affected many things in employees' attitudes and behaviors. Appelbaum et al (2007) listed things affected by workplace romance including: productivity, job satisfaction, mood and work spirits, tendency of favoritism, employees' morale and working climate, promotion and demotion, and sexual harassment law suit if the relationship ends badly.

Karl and Sutton (2000) said if workplace romance gives negative impact, organization should take strict action. However if workplace romance gives positive impact, lenient action is the most appropriate to exercise. The choice of policies must be carefully examined. Policies with sensible approach considered as the best option. In sensible approach, organization does not prohibit workplace romance and punish the couple. Organization must see the effect before deciding to give strict or lenient action. Karl and Sutton (2000) classified strict action responding workplace romance including; giving written warning, rotating or transferring employees engaged in workplace romance, and terminating; while lenient action including; organization doing nothing, giving counseling, and giving verbal warning.

Karl and Sutton (2000) listed the direct effect of workplace romance, they are; productivity increasing of couple engaged in romance, productivity decreasing of couple engaged in romance, the co-workers feel angry, and the visibility of emotional affection. If workplace romance makes the productivity of employees decreasing, strict action might be imposed. Karl and Sutton found even though there are some productivity decreasing, the most fair policies perceived by the employees is written warning and transfer/rotation, while termination perceived as not fair and only chosen as the last option. However if workplace romance gives good or positive effects, lenient action is the correct one. Counseling perceived as the best option responding workplace romance, moreover if the employees productivity increasing, employees perceived organization doing nothing as the fairest policies.

\section{Organizational Justice}

Organizational justice is the main element for organization to perform effectively (Forret and Love, 2008). It is proven that organizational justice has effect on job satisfaction, 


\section{Muhammad Irfan Syaebani \\ Riani Rachmawati}

organizational commitment, organizational citizenship behavior, and productivity (CohenCharash and Spector, 2001; Colquitt et al, 2001; Viswesvaran and Ones, 2002; in Forret and Love, 2008). Therefore, it is very important for organization to consider justice perception when formulating policies concerning romance in the workplace.

According to Adams (1965, in Forret and Love, 2008) organizational justice is based on employees' fariness perception. Literatures mention there are 3 kinds of organizational justice; distributive justice, procedural justice, and interactional justice. Deutsch (1985 in Bryne, 2005) defined distributive justice as fariness perception about outcomes and resources allocation. While procedural justice is fairness perception concerning policies or process used to make or to formulate decisions and rules about how resources should be allocated (Thibaut and Walker, 1975 in Bryne, 2005). Interactional justice is about perception of how well an employee is treated with respect and dignity during policies and rules implementation. Communication and good interpersonal relationship are the key.

Related to workplace romance, organization must ensure that policies formulated to respond the phenomenon has been made by fair process (Karl and Sutton, 2000). Karl and Sutton (2000) found on their research, workplace romance policies are fair if it based on the impact. That is the reason why organization must pay attention to the employees' fairness perception in order to make the correct policies. Incorrect policies will lead to mismanagement. If it occured then organization will experience bad impact because of the policies not because of the romance itself.

\section{RESEARCH HYPOTHESES}

Based on theoritical analysis, the research hypotheses are as follow:

1. Research Hypotheses 1: Policies concerning romance in the workplace in general will be viewed as more fair if it is lenient rather than strict. Romance is something personal and private. Organization has no right to intervene unless the romance caused negative impact to the organization. This argument is based on research of Karl and Sutton (2000) and Foley and Powell (1999).

2. Research Hypotheses 2: Strict policies are viewed as more fair if imposed to the romance involving hierarchical relationship. The possibilities of bad impact because hierarchical romance relationship are bigger. There might be jelousy from co-workers, favoritism, and litigation risk of sexual harassment if the relationship ends. Karl and Sutton (2000) and Foley and Powell (1999) support this argument.

3. Research Hypotheses 3: Strict policies are viewed as more fair if imposed to the couples come from the same departement/division rather than to those come from 


\section{Jurnal Manajemen Teori dan Terapan \\ Tahun 10. No. 2, Agustus 2017}

different department/division. If the couples come from the same department/division and work in the same area it might lead to the occurrence of jealousy from co-workers. They might feel distracted and lose concentration in doing work because of the intimacy showed by the couple. Co-workers might be angry and experience discomfort. The good working climate declines lead to the lower productivity and performance. Research findings of Karl and Sutton (2000) and Foley and Powell (1999) are behind this proposition.

4. Research Hypotheses 4: Strict policies are viewed as more fair if imposed to the relationship caused bad impact to the organization rather than to the relationship caused good impact to the organization. As already mentioned before, romance is something personal and private so that organization should not intervene. The organzation could take any action if only the romance gives negative impact to the organzation. The strict policies are aimed to protect the interest of organzation and to ensure the organzation existence is guaranteed. This conclusion is based on argument of Karl and Sutton (2000) and Foley and Powell (1999).

\section{RESEARCH METHOD}

\section{Operational Concepts}

To answer the research hypotheses, quasi experiment with scenario instrument is chosen. This method is the same with that of Karl and Sutton (2000). Quasi experiment is part of experiment method but in quasi experiment the groups and the variables could not fully controlled. Therefore this method is not pure experiment (Sevilla et al, 1993).

Operational of concept in this research are as follow:

1. Workplace romance is any relationship involving two persons work in the same organization and both of them have mutual attraction (Ariani, Ebrahimi, dan Saeedi, 2011). The concept excludes homosexual relationship, extra-marital affair, and relationship with marriage status (husband and wife relationship).

2. Types of relationship are status or level of job held by the couple. Types of relationship are classified into 2: lateral and hierarchical. Lateral is the relationship which the persons come from the same level of job in organization. While hierarchical is the relationship which the persons come from different level of job. In this concept, hirerachical relationship means men are in higher position. Relathionship which places women in higher position in office is excluded (Karl dan Sutton, 2000). 


\section{Muhammad Irfan Syaebani \\ Riani Rachmawati}

3. Couple origin is the department/division where they work. Couple origin could be from the same department which mean they work in the same area or from different department/division which mean they do not work together (Karl dan Sutton, 2000).

4. Relationship impact is the effect caused by the romance relation in the workplace. The effects could be both positive and negative. The positive effect of romance relation is the raised of couple's performance. While the negative effects of romance relation are performance decreasing, angry co-workers, and visible affection (Karl dan Sutton, 2000).

5. Policies are action taken by organization in responding workplace romance. Policies are classified into 2 categories; strict and lenient. Strict policies consist of giving written warning, transfer/rotation, and termination. Lenient policies are organization doing nothing, organization giving counseling to the couple, and organization giving verbal reprimand (Karl dan Sutton, 2000).

6. Justice perception is individual perception given by the research subject toward various policies imposed in responding the variation of workplace romance. The variation based on types of relationship, couple origin, and relationship impact. This perception is measured using likert scale 1 to 9. The higher the number given by respondent it means they view the policies as more fair to implement in responding a variation of workplace romance (Karl dan Sutton, 2000).

\section{Instrument}

There are 4 independent variables and 1 dependent variable in this research. Independent variables are manipulated into stories/scenarios. These scenarios then delivered to the research subjects. Research subjects give score of justice perception on every scenarios. The scores given by research subject are the dependent variable of this research. In brief, research variables are summarized in table 1.

Table 1. Research Variables

\begin{tabular}{|c|c|}
\hline \multicolumn{2}{|c|}{ Research Variables } \\
\hline $\begin{array}{c}\text { Independent Variables } \\
\text { a. Lateral } \\
\text { b. Hierarchical }\end{array}$ & \\
\hline $\begin{array}{c}\text { Couple Origin: } \\
\text { a. Same Department } \\
\text { b. Different Department }\end{array}$ & \\
\hline Relationship Impact: & \\
\hline
\end{tabular}




\begin{tabular}{|c|c|}
\hline $\begin{array}{l}\text { a. Performance Increasing } \\
\text { b. Performance Decreasing } \\
\text { c. Angry Co-workers } \\
\text { d. Public Display Affection/Visible } \\
\text { Affection }\end{array}$ & \\
\hline $\begin{array}{l}\text { Policies: } \\
\begin{array}{l}\text { a. Organization doing nothing } \\
\text { b. Organization giving counseling. } \\
\text { c. Organization giving verbal } \\
\text { reprimand.. } \\
\text { d. Organization giving written } \\
\text { warning } \\
\text { e. Transfer/Rotation } \\
\text { f. Termination }\end{array}\end{array}$ & \\
\hline
\end{tabular}

Every research subjects are given scenarios displaying type of relationship (lateralhierarchical), couple origin (same department-different department), and relationship impact (Performance Increase-Performance Decrease-Angry Coworkers-Public Display Affection). After reading the scenarios, research subject then asked to give score for 6 policies to be taken for every workplace romance variations based on justice perception in 1 to 9 scale where 1 is very unfair and 9 is very fair. At last, there will be 96 combinations of workplace romance based on 4 independent variables: types of relationship, couple origin, relationship impact, and policies as presented in table 2. The combination of 96 different workplace romances is presented into stories in 16 scenarios. 
Table 2. Data Matrix

\begin{tabular}{|c|c|c|c|c|c|c|c|c|}
\hline \multirow{2}{*}{$\begin{array}{c}\text { Types of } \\
\text { Relationship } \\
\text { (X1) }\end{array}$} & \multirow{2}{*}{$\begin{array}{l}\text { Couple } \\
\text { Origin } \\
(x 2)\end{array}$} & \multirow{2}{*}{$\begin{array}{c}\text { Relationship } \\
\text { Impact } \\
\text { (X3) }\end{array}$} & \multicolumn{6}{|c|}{ Policies (X4) } \\
\hline & & & 1 & 2 & 3 & 4 & 5 & 6 \\
\hline \multirow[t]{8}{*}{ Lateral (L) } & \multirow[t]{4}{*}{ Same (S) } & Increase (I) & LSII & LSI2 & LSI3 & LSI4 & LSI5 & LSI6 \\
\hline & & $\begin{array}{l}\text { Decrease } \\
\text { (D) }\end{array}$ & LSDI & LSD2 & LSD3 & LSD4 & LSD5 & LSD6 \\
\hline & & Angry (A) & LSAI & LSA2 & LSA3 & LSA4 & LSA5 & LSA6 \\
\hline & & Visible (V) & LSVI & LSV2 & LSV3 & LSV4 & LSV5 & LSV6 \\
\hline & \multirow{4}{*}{$\begin{array}{l}\text { Different } \\
\text { (D) }\end{array}$} & Increase (I) & LDI 1 & LDI2 & LDI3 & LDI4 & LDI5 & LDI6 \\
\hline & & $\begin{array}{l}\text { Decrease } \\
\text { (D) }\end{array}$ & LDDI & LDD2 & LDD3 & LDD4 & LDD5 & LDD6 \\
\hline & & Angry (A) & LDAI & LDA2 & LDA3 & LDA4 & LDA5 & LDA6 \\
\hline & & Visible (V) & LDV1 & LDV2 & LDV3 & LDV4 & LDV5 & LDV6 \\
\hline \multirow{8}{*}{$\begin{array}{l}\text { Hierarkikal } \\
(\mathrm{H})\end{array}$} & \multirow[t]{4}{*}{ Same (S) } & Increase (I) & $\mathrm{HSI}$ & $\mathrm{HSI} 2$ & $\mathrm{HSI3}$ & $\mathrm{HSI} 4$ & HSI5 & $\mathrm{HSI} / 6$ \\
\hline & & $\begin{array}{l}\text { Decrease } \\
\text { (D) }\end{array}$ & HSDI & HSD2 & HSD3 & HSD4 & HSD5 & HSD6 \\
\hline & & Angry (A) & HSAl & HSA2 & HSA3 & HSA4 & HSA5 & HSA6 \\
\hline & & Visible (V) & HSVI & HSV2 & HSV3 & HSV4 & HSV5 & HSV6 \\
\hline & \multirow{4}{*}{$\begin{array}{l}\text { Different } \\
\text { (D) }\end{array}$} & Increase (I) & HDI 1 & HDI2 & HDI3 & $\mathrm{HDI} 4$ & HDI5 & HDI6 \\
\hline & & $\begin{array}{l}\text { Decrease } \\
\text { (D) }\end{array}$ & HDDI & HDD2 & HDD3 & HDD4 & HDD5 & HDD6 \\
\hline & & Angry (A) & HDAl & HDA2 & HDA3 & HDA4 & HDA5 & HDA6 \\
\hline & & Visible (V) & HDV 1 & HDV2 & HDV3 & HDV4 & HDV5 & HDV6 \\
\hline
\end{tabular}

On the end of every scenarios, research subjects must answer questions as manipulation check procedure. Manipulations are given related to types of relationship and couple origin. To avoid cognitive overload, a condition where a research subjects experience mental exhausted because of too many questions to answer, the scenarios delivered to research subjects only a half of exsisting scenarios or 8 scenarios. Every research subjects got only workplace romance combination lateral or workplace romance combination hierarchical. 


\section{Jurnal Manajemen Teori dan Terapan \\ Tahun 10. No. 2, Agustus 2017}

\section{RESEARCH SUBJECTS}

As many as 30 people agreed to partake. They are student of Master of Management in Universitas Indonesia. The subject must fulfill the criteria prior participation. They must be still working, working but on educational leave, or have worked but no longer work because of study. Student who never experience working environment can not participate. All research hypotheses are tested using Analysis of Variance (ANOVA) one way and two way.

\section{Data Collection}

In total, 240 scenarios were collected from 30 research subjects. Every subject must fill in 8 scenarios out of 16 scenarios provided (a half of exsisting scenarios). Thus 240 is total of 8 scenarios filled by every research subjects $(8 * 30=240)$. Of total 240,58 scenarios are unable to be processed because failed in manipulation check. It means only 182 scenarios could be processed reached $75.83 \%$ of response rate.

From total 30 research subject, 12 persons are men (40\%) and 18 persons are women (60\%). Average age of the research subjects is 27.7 years with the oldest respondent is 34 years old and the youngest is 22 years old. As many as 18 persons were single (60\%) and 12 persons were married (40\%). In total, 12 persons are working or have worked in public sector (40\%), 3 persons are working or have worked in State Owned Enterprises (10\%), 8 persons are working or have worked in national private company $(27 \%)$, and 7 persons are working or have worked in multinational private company (23\%). Average tenure is 4.23 years with the longest tenure 12 years and the shortest tenure is 0.5 year.

\section{Discussion and Analysis}

As many as 24 research subjects or $80 \%$ admitted they ever found workplace romance during their working experience. This finding showed that workplace romance as something real and prevalent in organization dynamics in Indonesia. This finding supported previous research in many countries such as United States, India, Canada, Taiwan, and Israel (Mano dan Gabriel, 2006; Kumar, 2012). Workplace romance is something inevitable. Workplace romance is a fact, something usual in work space (Binetti, 2007).

Currently, interaction among employees not only for professional relation but also for private and personal relation (Rabin-Margalioth, 2006). The limit between professional sphere and personal sphere becomes blur. Therefore, it is obsolete if organization tries to adopt old fashioned action which trying to segregate employees' professional and personal life in inflexible way. Today both spheres, professional and personal, are intertwined and affecting one another (Rabin-Margalioth, 2006). 


\section{Muhammad Irfan Syaebani \\ Riani Rachmawati}

The $1^{\text {st }}$ hypotheses of this research is; policies concerning romance in the workplace in general will be viewed as more fair if it is lenient rather than strict. It means workers consider policies as more fair if it is not coercive without seeing the impact might be caused by the relationship. From one way ANOVA test it is proved that there is difference between one policies to others with counseling perceived as the most fair policy to force as can be seen on table 3. In post hoc comparison test, termination is policy which pairs of means cause the significant differences. In conclusion, research hypothesis 1 is accepted.

Table 3. Rank of Romance Policies based on Justice Perception in General

\begin{tabular}{|l|c|}
\hline \multicolumn{1}{|c|}{ Policies } & Mean \\
\hline Counseling & 5.50 \\
\hline $\begin{array}{l}\text { Organization doing } \\
\text { nothing }\end{array}$ & 4.82 \\
\hline Verbal Reprimand & 4.72 \\
\hline Rotation/Transfer & 4.59 \\
\hline Written warning & 3.94 \\
\hline Termination & 1.75 \\
\hline
\end{tabular}

Table 4. ANOVA Table of Hypothesis 1

\begin{tabular}{|c|c|}
\hline $\mathbf{F}$ & Sig \\
\hline 69.594 & 0.00 \\
\hline
\end{tabular}

This finding is in accordance with argument of Pierce, Karl, and Brey (2012) who stated lenient policies viewed as the most fair policies to enforce. Romance is something private so that organization does not need to get involve too much. Giving counseling is perceived as the proper one.

Workplace romance could be classified based on types of relationship. The relationship could be lateral which means couple involve in the bond is equal in level of job. While hierarchical relationship means that the man is higher in job position compare to the woman.

Specifically this research tries to reveal which policies perceived as the most fair for lateral and hieararchical workplace romance. Research hypothesis 2 stated: Strict policies are viewed as more fair if imposed to the romance involving hierarchical relationship. It is because the possibilities of hierarchical relationship creates bad impact will be higher compare to lateral relationship. Jealousy and favoritism might be occurred and it will destroy good working climate. 


\section{Jurnal Manajemen Teori dan Terapan \\ Tahun 10. No. 2, Agustus 2017}

To find out whether significant or not the justice perception of policies based on type of relationship, two way ANOVA test was performed. The result showed that there is significant justice perception of policies based on types of relationship. If it is ranked from the most fair policies to the most unfair policies, the order is as prsented in table 5. In post hoc comparison test, counseling, written warning, and termination are policies which pairs of means cause the significant differences.

Table 5. Rank of Romance Policies based on Type of Relationship

\begin{tabular}{|l|c|l|c|}
\hline \multicolumn{2}{|c|}{ Lateral } & \multicolumn{2}{c|}{ Hierarchical } \\
\hline Policies & Mean & \multicolumn{1}{c|}{ Policies } & Mean \\
\hline Counseling & 5.35 & Counseling & 5.64 \\
\hline Organization doing nothing & 5.10 & Verbal rerpimand & 5.03 \\
\hline Verbal reprimand & 4.36 & Rotation/Transfer & 4.93 \\
\hline Rotation/Transfer & 4.23 & $\begin{array}{l}\text { Organization doing } \\
\text { nothing }\end{array}$ & 4.56 \\
\hline Written warning & 3.62 & Written warning & 4.23 \\
\hline Termination & 1.93 & Termination & 1.58 \\
\hline
\end{tabular}

Table 6. ANOVA Table of Hypothesis 2

\begin{tabular}{|c|c|}
\hline $\mathbf{F}$ & Sig \\
\hline 3.039 & 0.010 \\
\hline
\end{tabular}

From table 4, we can conclude that for hierarchical relationship wokers perceived it is more fair if the strict policies are imposed compare to lateral relationship. It means research hypothesis 2 is accepted with one condition; strict policies can be imposed after organization gives counseling. If after counseling was given the hierarchical workplace romance relationship breeds negative impact then strict policies follow to be implemented.

This result is supported by argument of Powell (1986), Mainiero (1986), Powell (1993), and Pierce et al. (1996) which cited by Foley and Powell (1999). They stated that hierarchical workplace romance relationship usually caused negative impact. Moreover the negative impact will be higher if this hierarchical relationship changes into marriage (Schwartz and Storm, 2000 in Kumar, 2012).

This finding also confirm argument of Pierce, Karl, and Brey (2012). They stated that romance policies must follow sensible approach principle which means strict policies can not be implemented directly when hierarchical relationship occurred. Research subjects agreed 


\section{Muhammad Irfan Syaebani \\ Riani Rachmawati}

that counseling as the most fair policies and strict policies followed if counseling can not prevent the occurence of bad impacts.

Refer to the literatures, workplace romance could be classified based on origin of couple. Karl and Sutton (2000) stated that couple who work in the same department will give higher possibilities of bad impact rather than couple who work in different department. Couple from the same department will have more intense interaction. This will lead to the jealousy from coworkers, feeling of discomfort, and distraction. Therefore strict policies is the correct one to impose on couples from the same department.

The proposition is tested on research hypotheses 3: Strict policies are viewed as more fair if imposed to the couples come from the same departement/division rather than to those come from different department/division.

Based on response given by research subject it reveals the order of policies from the most fair to the most unfair classified by couple origin for couple from same departement is counseling followed by rotation/transfer, verbal reprimand, organization doing nothing, written warning, and termination while for couple from different departement is counseling followed by organization doing nothing, verbal reprimand, rotation/transfer, written warning, and termination. To test whether there is difference justice perception of romance policies based on couple origin or not, two way ANOVA is performed. The result showed there is insignificant. It means justice perception of romance policies based on couple origin is the same from one to another. The order or rank of policies is void.

Table 7. Rank of Romance Policies based on Couple Origin

\begin{tabular}{|l|c|l|c|}
\hline \multicolumn{1}{|c|}{ Same } & \multicolumn{1}{c|}{ Different } \\
\hline \multicolumn{1}{|c|}{ Policies } & Mean & \multicolumn{1}{c|}{ Policies } & Mean \\
\hline Counseling & 5.75 & Counseling & 5.19 \\
\hline Rotation/Transfer & 4.80 & $\begin{array}{l}\text { Organization doing } \\
\text { nothing }\end{array}$ & 4.93 \\
\hline Verbal reprimand & 4.79 & Verbal reprimand & 4.62 \\
\hline $\begin{array}{l}\text { Organization doing } \\
\text { nothing }\end{array}$ & 4.72 & Rotation/Transfer & 4.34 \\
\hline Written warning & 4.08 & Written warning & 3.77 \\
\hline Termination & 1.80 & Termination & 1.68 \\
\hline
\end{tabular}


Table 8. ANOVA Table of Hypothesis 3

\begin{tabular}{|c|c|}
\hline $\mathbf{F}$ & Sig \\
\hline 0.772 & 0.570 \\
\hline
\end{tabular}

Research hypotheses 3 which stated strict policies must be given to the couple from the same departement is rejected. The reason behind this rejection might be; people love to see other people fall in love. When love is in the air, positive aura is spreading. As a result people will be affected by the positive love energy (Karl dan Sutton, 2000).

Even though many literatures predicted there will be different perception of justice perception of relationships based on couple origin but this finding denied that argument. This finding is similar of Karl and Sutton's (2000). When formulating proposition, Karl and Sutton believed that there will be different justice perception, but then they found the difference is insignificant. However this finding needs to be elaborated since there is inconsistency among one finding to others. Cole's (2009) finding contradicted with Karl and Sutton's finding and our finding.

Research hypotheses 4 tries to investigate justice perception of romance policies based on impacts. There are 4 impacts might be resulted from workplace romance, they are; performance increase (which is positive), performance decrease, angry co-workers, and public display affection/visible (which are negative). From those 4 impacts, research subjects were asked which policies perceived the most fair to be implemented.

Research hypotheses 4 is: Strict policies are viewed as more fair if imposed to the relationship caused bad impact to the organization rather than to the relationship caused good impact to the organization.

Result analysis showed if romance gives bad impact such as performance decreasing and angry co-workers, the most fair policy perceived by research subjects is counseling. If the impacts given by workplace romance are performance increasing and public display affection, the most fair policy is organization doing nothing. To test the difference, two way ANOVA was performed.

The result showed there is significant differences on justice perception of romance policies based on impacts. Order of policies from the most fair to the most unfair based on impact presented in table 9. In post hoc comparison test, counseling, written warning, and termination are policies which pairs of means cause the significant differences. Thus, research hypotheses 4 which stated that strict policies can be implemented if romance gives 


\section{Muhammad Irfan Syaebani \\ Riani Rachmawati}

bad effect is accaepted, but research subjects still believed strict policies are implemented after organization gave counseling. Counseling still perceived as the most fair policy even if the romance gives bad consequences to organization. If the impact is not bad at all or not endanger the perfomance of organization as a whole then doing nothing perceived as the most fair policy.

Table 9. Rank of Romance Policies based on Relationship Impact

\begin{tabular}{|l|l|l|l|l|l|l|l|}
\hline \multicolumn{2}{|c|}{ Performance Increasing } & \multicolumn{1}{c|}{ Performance Decreasing } & \multicolumn{2}{c|}{ Angry Co-Workers } & \multicolumn{2}{c|}{ Public Display Affection } \\
\hline \multicolumn{1}{|c|}{ Policies } & Mean & \multicolumn{1}{|c|}{ Policies } & Mean & \multicolumn{1}{c|}{ Policies } & Mean & \multicolumn{1}{c|}{ Policies } & Mean \\
\hline $\begin{array}{l}\text { Organization } \\
\text { doing nothing }\end{array}$ & 5,83 & Counseling & 6,69 & Counseling & 5,35 & $\begin{array}{l}\text { Organization } \\
\text { doing nothing }\end{array}$ & 5,58 \\
\hline Counseling & 4,84 & $\begin{array}{l}\text { Verbal } \\
\text { reprimand }\end{array}$ & 6,45 & Rotation/Transfer & 4,49 & Counseling & 5,21 \\
\hline Rotation/Transfer & 4,02 & Rotation/Transfer & 6,41 & $\begin{array}{l}\text { Organization } \\
\text { doing nothing }\end{array}$ & 4,41 & $\begin{array}{l}\text { Verbal } \\
\text { reprimand }\end{array}$ & 4,63 \\
\hline $\begin{array}{l}\text { Verbal } \\
\text { reprimand }\end{array}$ & 3,62 & Written warning & 5,67 & $\begin{array}{l}\text { Verbal } \\
\text { reprimand }\end{array}$ & 4,33 & Written warning & 3,84 \\
\hline Written warning & 2,87 & $\begin{array}{l}\text { Organization } \\
\text { doing nothing }\end{array}$ & 3,46 & Written warning & 3,53 & Rotation/Transfer & 3,51 \\
\hline Termination & 1,27 & Termination & 2,63 & Termination & 1,61 & Termination & 1,56 \\
\hline
\end{tabular}

Table 10. ANOVA Table of Hypothesis 4

\begin{tabular}{|c|c|}
\hline $\mathbf{F}$ & Sig \\
\hline 9.441 & 0.000 \\
\hline
\end{tabular}

This finding supports many arguments on many literatures such as; Karl and Sutton, (2000); Cole, (2009); Appelbaum, Marinescu, Klenin, and Bytautas (2007); and Rabin-Margalioth (2006).

From this research it revealed that giving counseling is the most fair policy in responding workplace romance in general, romance with hierarchical type, romance with lateral type, and romance with negative impacts. Direct supervisor is the one who interact intensely with workers and has HR roles such as become an employees advocate. If direct supervisor can not give counseling, the responsibility moves to HR division of the organization. 


\section{Jurnal Manajemen Teori dan Terapan \\ Tahun 10. No. 2, Agustus 2017}

Giving counseling is considered as policy using sensible approach. Organization using sensible approach means organization does not fully prohibit workplace romance and punishes all the parties involved (Pierce, Karl, and Brey, 2012). Organization using sensible approach will take steps carefully in formulating workplace romance policies. One indicator in formulating sensible approach policies is that the policies must consider the employees' justice perception. Moreover, Aquino et al (2014) stated that social sexual behavior, which involeving romantic relationship, is an inescapable feature of human interaction. Thus, organization must pay enough and fair attention regarding this phenomenon.

Termination perceived as the most unfair policy even if the romance gives bad impact to the organization. Coercive approach is considered as unrelevant in responding workplace romance. Kolesnikova and Analoui (2013) stated organization should formulate policies which perceived by employees as fair and well-justified. Workplace romance is something usual and normal in organization dynamics and punished it denying the fact (Binetti, 2007). The organization's role in responding workplace romance is ensuring the climate of organization to be positive and preventing romantic relation turns into sexual harassment, especially in digital era when social media technologies can be utilised as means of harassment (Mainero and Jones, 2013).

Beside fair perception, organization also must be aware of individual characteristic differences in formulating workplace romance policies. In this research, individual differences are excluded from the design research while in fact individual characteristic such as personality may contribute to the complexity of intercation of romance in the workplace (Doll and Rosopa, 2015).

\section{CONCLUSION AND RESEARCH LIMITATION}

In general counseling perceived as the most fair policy in responding workplace romance. Counseling also viewed as the most proper policy in responding hierarchical and lateral type relationship. However for hierarchical type relationship the next policy after counseling is giving verbal reprimand which is more strict compare to lateral type relationship which organization doing nothing perceived more fair policy after counseling.

Justice perception of policies in responding workplace romance based on couple origin is insignificant. Thus, all policies considered as indifference.

Counseling perceived as the most fair policy to give if the romance gives bad impact to organization such as performnace decreasing and angry co-workers, but if the impact is positive such as performance increasing organization doing nothing is the most suitable 


\section{Muhammad Irfan Syaebani \\ Riani Rachmawati}

policy to impose. If the couple showed public display affection, organization doing nothing still believed as the most proper one since it is not endanger the organization existance.

This research has several limitations. This limitation must be anticipated for further research. The first; this research is not pure experiment. It means not all variables which may contribute to the response given by respondents can be controlled and isolated. The second; bias in response might occured. Bias in response might caused by noise felt by respondents during the process of data intake. Sound pollution is the main noise during the process. The room used for data intake can not isolated the sound effectively. It may lead to the research subjects lost concentration because felt distracted.

Bias might also occured because of order effect. The order of scenarios in every booklet is the same. This bias is detected during manipulation check process. Many scenarios in the first and the last order can not passed the manipulation test compare to the scenarios in the middle. The reason why many scenarios in the first order failed perhaps because respondents still confuse with the instruction and the rule of the game. While the reason why many scenarios in the last order also failed maybe because respondent already feel exhausted filling and answering so many questions.

\section{REFFERENCE}

Appelbaum, S. H., Marinescu, A., Klenin, J., and Bytautas, J. 2007. Fatal attraction: The (mis) management of workplace romance. International Journal of Business Research, 7(4), 31-47.

Aquino, K., Sheppard, L., Watkins, M. B., O'Reilly, J., and Smith, A. 2014. Social sexual behavior at work. Research in Organizational Behavior, 34, 217-236.

Ariani, M. G., Ebrahimi, S. S., and Saeedi, A. 2011. Managing workplace romance: A headache for human resource leaders. 2011 3rd International conference on Advance Management Science, IPEDR. 19, 99-103.

Badan Pusat Statistik. 2012. Berita Resmi Statistik (Official Statistics News). No 33/05/Th. XV. 1-5.

Binetti, M. S. 2007. Romance in the workplace: When 'love' becomes litigation. Hofstra Labor and Employment Law Journal, 25, 153-172

Bordwin, M. 1994. Containing cupid's arrow. Small Business Report, 19(7), 53-57

Boyd, C. 2010. The debate over the prohibition of romance in the workplace. Journal of Business Ethics, 97, 325-338.

Bryne, Z. S. 2005. Fairness reduces the negative effects of organizational politics on turnover intentions, citizenship behavior, and job performance. Journal of Business and Psychology, 20(2), 175-200. 


\section{Jurnal Manajemen Teori dan Terapan \\ Tahun 10. No. 2, Agustus 2017}

Cole, N. 2009. Workplace romance: A justice analysis. Journal of Business Psychology, 24(1), 363-372.

Doll, J., and Rosopa, P. J. 2015. Workplace romance: Examiningattitudes experience, conscientiousness, and policies. Journal of Managerial Psychology, 30(4), 439-453.

Foley, S. and Powell, G. N. 1999. Not all is fair in love and work: coworkers' preference for and responses to managerial interventuons regarding workplace romances. Journal of Organizational Behavior, 20(7), 1043-1056.

Forret, M., and Love, M. S. 2008. Employee justice perception and coworker relationships. Leadership and Organization Development Journal, 29(3), 248-260.

Gautier, C. 2007. Managing romance in the workplace. Journal of Employee Assistance, $1^{\text {st }}$ Quarter 2007, 7-9.

Karl, K. A., and Sutton, C. L. 2000. An examination of the perceived fairness of workplace romance policies. Journal of Business and Psychology, 13(3), 429-442.

Kolesnikova, J. and Analoui, F. 2013. Managing human resource romance at work: towards a "considerate" approach. Journal of Management Development, 32(1), 36-56.

Kumar, S. 2012. Managing workplace romance: An emerging challenge for human resource leaders in corporate world. National Conference on Emerging Challenge for Sustainable Business 2012, 955-964.

Lickey, N. C., Berry, G. R., and Whelan-Berry, K. S. 2009. Responding to workplace romance: A proactive and pragmatic approach. The Journal of Business Inquiry, 8(1), 100-119.

Mainero, L. A. and Jones, K. J. 2013. Workplace romance 2.0: Developing a communication ethics model to address potential sexual harassment from inappropriate social media contacts between coworkers. Journal of Business Ethics, 114, 367-379.

Mano, R., and Gabriel, Y. 2006. Workplace romances in cold and hot organizational climates: The experience of Israel and Taiwan. Human Relation, 59(1), 7-35.

Parks, M. .2006. Workplace romance poll findings. Virginia USA: Society for Human Resource Management.

Parks, M. 2010. Workplace romance: poll findings society for human resource management. Wall Street Journal, 11 (2), 312-323.

Pierce, C. A., Bryne, D., and Aguinis, H. 1996. Attraction in organization: a model of workplace romance. Journal of Organizational Behavior, 17(1), 5-32.

Pierce, C. A., and Aguinis, H. 2001. A framework for investigating the link between workplace romance and sexual harassment. Group and Organization Management, 26(2), 206229.

Pierce, C. A., and Aguinis, H. 2003. Romantic relationship in organizations: a test of a model of formation and impact factors. Management Research, 1(2), 161-169.

Pierce, C. A., Karl, K. A., and Brey, E.T. 2012. Role of workplace romance policies and procedures on job pursuit intentions. Journal of Managerial Psychology, 27(3), 237-263. 


\section{Muhammad Irfan Syaebani}

\section{Riani Rachmawati}

Rabin-Margalioth, S. 2006. Love at work. Duke Journal of Gender Law and Policy, 13, 237-253.

Sevilla, C. G., Ochave, J. A., Punsalan, T.G., Regala, B. P., and Uriarte, G. G., 1993. Pengantar metode penelitian (introduction to research method). Jakarta: UI Press Penerbit Universitas Indonesia 